Jurnal Abdidas Volume 2 Nomor 5 Tahun 2021 Halaman 1154 - 1158

JURNAL ABDIDAS

http://abdidas.org/index.php/abdidas

\title{
Pelatihan Manajemen Kelas pada Mata Pelajaran Matematika di SD IT Az-Zahra Takengon, Kabupaten Aceh Tengah
}

\author{
Rosliana Harahap $^{1 \bowtie}$, Nurul Qomariyah Ahmad $^{2}$, Ali Umar ${ }^{3}$, Nurmalina $^{4}$ \\ IAIN Takengon, Indonesia ${ }^{1,2,3,4}$ \\ E-mail : r05liana007@gmail.com ${ }^{1}$, qomariyahnrl@gmail.com² ${ }^{2}$, panghulurajo86@gamail.com ${ }^{3}$, \\ nurmalina125@gmail.com ${ }^{4}$
}

\begin{abstract}
Abstrak
Manajemen kelas pada pembelajaran matematika yaitu pengelolaan terhadap bidang studi matematika melalui perencanaan, pelaksanaan, dan evaluasi pembelajaran. Manajemen pembelajaran matematika di kelas di susun dalam bentuk RPP yang baik. RPP yang baik harus memiliki, pendahuluan pembelajaran, menyampaikan tujuan, mampu menggali pengetahuan siswa, penjelasan materi, penjelasan media yang digunakan, penugasan dan evaluasi. RPP yang baik akan membantu guru dalam proses pembelajaran, sehingga tujuan dari proses pembelajaran dapat tercapai. Namun untuk merancang RPP yang baik tidaklah mudah, untuk itu perlu dilakukan pelatihan terhadap guru-guru agar mampu merancang RPP yang baik sehingga membantu para guru dalam proses pembelajaran di kelas. Pelatihan ini melibatkan 14 guru SD IT Az- Zahra sebagai peserta. Adapun langkah-langkah dalam pelatihan ini terdiri dari dua sesi, sesi pertama memberikan penjelasan materi tentang urgensi managemen kelas, dan managemen pelajaran matematika, pada sesi ke dua peserta melakukan praktik merancang manajemen kelas yang baik dalam bentuk RPP. Adapun target kegiatan pelatihan ini adalah keterampilan guru-guru dalam memanajemen pembelajaran di kelas matematika. Hasil dari pelatihan ini para peserta mampu meningkatkan keterampilan memanagemen kelas yang dituangkan dalam bentuk RPP, dan RPP yang dirancang oleh peserta dalam terkategori baik, hal ini terlihat dari RPP yang peserta buat telah sesuai dengan managemen waktu, managemen materi dan managemen penilaian.
\end{abstract}

Kata kunci: managemen, kelas, pembelajaran matematika, RPP

\section{Abstract}

Class management in mathematics learning is the management of the field of mathematics studies through planning, implementation, and evaluation of learning. The management of mathematics learning in the classroom is arranged in the form of a good lesson plan. A good lesson plan must have an introduction to learning, convey goals, be able to explore student knowledge, explain material, explain the media used, assignments and evaluations. A good lesson plan will help teachers in the learning process, so that the objectives of the learning process can be achieved. However, to design a good lesson plan is not easy, for that it is necessary to train teachers to be able to design good lesson plans so as to help teachers in the learning process in the classroom. This training involved 14 teachers of SD IT Az-Zahra as participants. The steps in this training consist of two sessions, the first session provides material explanations about the urgency of classroom management, and mathematics lesson management, in the second session participants practice designing good classroom management in the form of lesson plans. The target of this training activity is the skills of teachers in managing learning in mathematics classes. The results of this training the participants were able to improve their class management skills which were outlined in the form of lesson plans, and the lesson plans designed by the participants were categorized as good, this can be seen from the lesson plans that the participants made were in accordance with time management, material management and assessment management.

Keywords: management, classroom, learning mathematics, lesson plans

Copyright (c) 2021 Rosliana Harahap, Nurul Qomariyah Ahmad, Ali Umar, Nurmalina $\triangle$ Corresponding author

Address : Jl. Blank Kolak 2 Aceh Tengah

Email : r05liana007@gmail.com

DOI : https://doi.org/10.31004/abdidas.v2i5.446
ISSN 2721- 9224 (Media Cetak)

ISSN 2721- 9216 (Media Online) 
1155 Pelatihan Manajemen Kelas pada Mata Pelajaran Matematika di SD IT Az-Zahra Takengon, Kabupaten Aceh Tengah - Rosliana Harahap, Nurul Qomariyah Ahmad, Ali Umar, Nurmalina DOI: https://doi.org/10.31004/abdidas.v2i5.446

\section{PENDAHULUAN}

Ilmu manajemen adalah suatu ilmu yang membantu kita mengatur atau menata hal-hal yang diperlukan. Contohnya manajemen waktu, sesorang siswa yang memilki manajemen waktu tidak akan terlambat ke sekolah, karena dia paham jam berapa harus bangun, sholat, sarapan dan berangkat ke sekolah. Sehingga manajemen sangat penting dimilki oleh guru kelas, agar dapat menyampaikan materi dengan baik dan tujuan dari pembelajaran dapat tercapai.

Pengajaran adalah serangkaian kegiatan yang bermaksud memfasilitasi peserta didik mencapai tujuan pendidikan secara langsung. Manajemen kelas merupakan segenap upaya guru dalam mengelola kegiatan pembelajaran guna mencapai tujuan pembelajaran yang telah ditetapkan secara efektif dan efisien. Manajemen kelas menentukan keberhasilan pembelajaran yang dilakukan guru dan siswa. Sehingga nampak jelas bahwa peran guru dalam manajemen kelas sangat menentukan keefektifan dari kegiatan pembelajaran yang dilakukan guru dan siswa. Manajemen kelas berasal dari dua kata yaitu manajemen dan kelas.

Menurut (G.R. Terry, 2010) managemen adalah suatu proses khas yang terdiri atas tindakan - tindakan perencanaan, pengorganisasian, penggerakan, dan pengendalian untuk menetukan serta mencapai tujuan melalui pemanfaatan sumber daya manusia dan sumber daya lainnya sedangkan kelas menurut (Suharsimi Arikunto, Suhardjono, 2007) kelas adalah sekelompok siswa yang belajar dalam waktu yang sama, menerima pelajaran yang sama dari guru yang sama pula. Manajemen kelas adalah keterampilan guru untuk menciptakan iklim pembelajaran yang kondusif dan mengendalikannya jika terjadi gangguan dalam pembelajaran (Euis Karwati, 2015), sedangkan menurut (Djamarah, 2006) manajemen kelas adalah suatu upaya memberdayagunakan potensi kelas yang ada seoptimal mungkin untuk mendukung proses interaksi edukatif guna mencapai tujuan pembelajaran.

Pembelajaran matematika di SD merupakan salah satu kajian yang selalu menarik untuk bahas karena adanya perbedaan karakteristik khususnya antara hakikat anak SD dan hakikat matematika. Anak usia SD sedang mengalami perkembangan pada tingkat berpikirnya. Ini karena tahap berpikir mereka masih belum formal, mereka masih berpikir secara konkret. Di lain pihak, matematika adalah yang bersifat abstrak. Mengingat adanya perbedaan karakteristik itu maka diperlukan kemampuan khusus dari seorang guru untuk menjembatani antara dunia anak yang belum berpikir secara abstrak agar dapat mengerti dunia matematika yang bersifat abstrak. Menurut (Suherman, 2003) matematika terbentuk sebagai hasil pemikiran manusia yang berhubungan dengan proses penalaran. Dan menurut (Subarinah, 2006). Matematika juga merupakan ilmu yang didalamnya terkandung konsep dan pola pola yang abstrak. Karena matematika pelajaran yang bersifat abstrak maka seorang guru harus memiliki keterampilan dalam mengelola kelas sehingga tujuan dari pembelajaran dapat tercapai, salah satu kemampuan yang harus dimilki oleh guru tersebut adalah managemen kelas.

Managemen kelas dapat dirancang dalam bentuk RPP, RPP yang baik harus memiliki a) Identitas mata pelajaran (nama pelajaran, kelas, semester, dan waktu atau banyaknya jam pertemuan yang dialokasikan). b) Standar kompetensi, kompetensi dasar dan indikator yang hendak dicapai atau dijadikan tujuan dapat dikutip/diambil dari kurikulum dan hasil belajar yang telah ditetapkan oleh pemerintah. c) Materi pokok (beserta uraiannya yang perlu dipelajari siswa dalam rangka mencapai kompetensi dasar). 
1156 Pelatihan Manajemen Kelas pada Mata Pelajaran Matematika di SD IT Az-Zahra Takengon, Kabupaten Aceh Tengah - Rosliana Harahap, Nurul Qomariyah Ahmad, Ali Umar, Nurmalina DOI: https://doi.org/10.31004/abdidas.v2i5.446

d) Media (yang digunakan untuk kegiatan pembelajaran) e) Strategi pembelajaran /skenario /tahapan-tahapan proses belajar mengajar yaitu kegiatan pembelajaran secara konkret yang harus dilakukan oleh guru dan siswa dalam berinteraksi dengan materi pembelajaran dan sumber belajar untuk menguasai kompetensi (Abdul Majid dan Chaerul Rochman, 2015). Namun kenyataan dilapangan masih banyak guru yang sulit merancang RPP secara optimal sehingga proses pembelajaran sulit untuk mencapai tujuan. Seperti pada paparan penelitian yang dilakukan oleh (Rezkiatu Novia Alhikmah, Yenita Roza, 2021) guru-guru masih mengalami kesulitan dalam buat RPP yang baik, dan kurangnya pelatihan dan seminar bagi guru-guru dalam membuat RPP sehingga perlu dilakukan pelatihan rutin terhadap guru-guru di sekolah.

Untuk itu dilakukan pelatihan guru-guru SD khususnya guru matematika SD. Dalam hal ini pelatihan dilakukan di SD IT Az-Zahra. Melalui pelatihan managemen kelas ini guru-guru dapat merancang RPP dengan baik sehingga proses pembelajaran dapat berjalan baik dan tujuan pembelajaran dapat tercapai.

\section{METODE}

Pelatihan ini dilaksanakan selama dua hari, pada hari pertama guru-guru diberikan pemahaman materi tentang managemen, managemen kelas, pelajaran matematika. Pada hari ke dua guru-guru melakukan praktek menggunakan managemen kelas yang dituangkan dalam disain RPP.

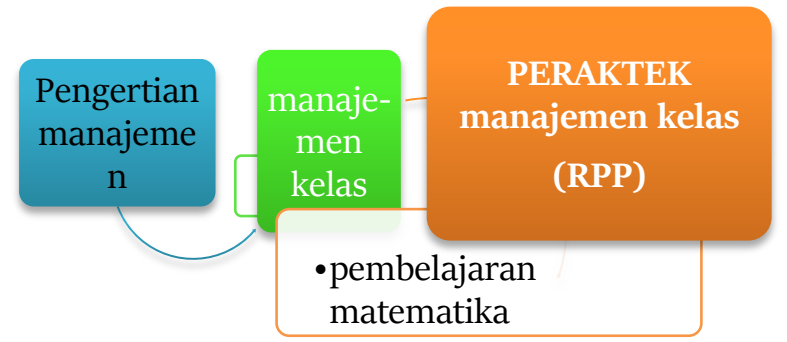

\section{Gambar 1. Alur Pelatihan}

Pelatihan ini melibatkan 4 orang narasumber, peserta pelatihan adalah guru-guru SD Az-Zahra yang berjumlah 14 orang. Sebelum kegiatan ini dilaksanakan, dilakukan konsultasi dengan kepala sekolah untuk memperoleh izin kegiatan dan mengatur tempat serta waktu kegiatan. Selanjutnya dilaksanakan kegiatan wawancara kepada guru SD IT Az-Zahra dengan tujuan mendapat imformasi yang akurat sehingga dapat merancang kegiatan pelatihan dengan baik. Setelah izin melaksanakan kegiatan pelatihan dari kepala sekolah SD IT Az-Zahra diperoleh maka tim merancang kegiatan, dengan membagi materi kepada keempat narasumber.

Adapun materi nya yaitu tentang manajemen kelas, materi ini dipilih karena banyak guru yang sulit mengatur alokasi waktu pembelajaran, pembagian materi, strategi pembelajaran yang tepat, yang semua itu merupakan bagian dari manajemen kelas, yang dituliskan dalam bentuk RPP.

\section{HASIL DAN PEMBAHASAN}

Kegiatan pelatihan ini melalui penyajian materi dan diskusi, kegiatan ini bertujuan untuk memberikan pemahaman peserta tentang kompetensi keterampilan memanajemen pembelajaran matematika di kelas dalam bentuk RPP yang baik. Secara umum kegiatan diskusi 
1157 Pelatihan Manajemen Kelas pada Mata Pelajaran Matematika di SD IT Az-Zahra Takengon, Kabupaten Aceh Tengah - Rosliana Harahap, Nurul Qomariyah Ahmad, Ali Umar, Nurmalina DOI: https://doi.org/10.31004/abdidas.v2i5.446

berlangsung sangat baik. Peserta sangat antusias dan bersungguh-sungguh mengikuti sesion demi session.

Demikian pula kegiatan diskusi berlangsung sangat baik. Respon peserta maupun tanggapan dari nara sumber berlangsung baik. Banyaknya pertanyaan yang muncul dari peserta menunjukkan adanya respon positif dari peserta terhadap materi pelatihan, disamping juga menunjukkan bahwa banyak hal yang masih perlu diketahui terkait dengan keterampilan memanajemen pembelajaran matematika matematika.

Hal lain yang dapat direkam dari kegiatan pelatihan adalah bahwa pengetahuan awal peserta tentang manajemen pembelajaran matematika masih minim. Namun setelah diberikan pelatihan, tingkat pemahaman peserta pelatihan menunjukkan hasil yang baik dengan mampunya guru membuat RPP yang baik.

Setelah pelatihan, para guru yang menjadi peserta pada umumnya telah mampu RPP yang mempergunakan manajemen kelas. Para peserta seluruhnya menyatakan bahwa setelah selesai mengikuti kegiatan ini mereka memperoleh tambahan berbagai informasi, pemahaman, kemampuan dan keterampilan yang baru tentang memanajemen kelas dalam pembelajaran matematika. Kepala Sekolah menyatakan rasa puas dan berterimakasih atas penyelenggaraan kegiatan ini, serta berharap agar guru-guru SD dapat mengembangkan RPP sesuai dengan manajemen yang baik sehingga tujuan belajar dapat tercapai.

Para guru bahkan Kepala Sekolah sangat antusias dalam mengikuti pelatihan. Hal ini dapat dilihat dari jumlah peserta sebanyak 14 orang guru. Para guru dengan senang mempraktekkan hasil diskusi mereka tentang RPP yang baik. Selama peserta pelatihan melakukan eksperimen, Tim Pengabdi mendampingi peserta sambil memberi tambahan konsep-konsep dasar
Matematika. Diskusi berlangsung baik, baik berkaitan dengan latar belakang materi, teori manajemen kelas, matematika, maupun membuatan RPP pembelajaran matematika SD. Hal ini menunjukkan bahwa rasa ingin tahu dan ingin maju. Dari hasil evaluasi, secara umum peserta menilai bahwa kegiatan semacam ini sangat bermanfaat bagi para guru, perlu diteruskan pada masa mendatang, dan dengan waktu yang lebih panjang agar lebih leluasa dalam mempelajari manajemen pembelajaran matematika SD.

Dari hasil pengamatan menunjukkan adanya perbedaan kemampuan memahami dari setiap peserta. Variasi pemahaman ini dapat didinjau dari aspek latar belakang peserta.

Hal ini menunjukkan bahwa target kegiatan pelatihan keterampilan memanajemen pembelajaran di kelas matematika yakni mampu meningkatkan keterampilan peserta pelatihan ratarata terkategori baik telah tercapai. Berdasarkan laporan kegiatan mandiri terpantau (praktek penerapan pelatihan) di sekolah diketahui bahwa keterampilan peserta setelah diberi pelatihan menjadi lebih baik. Hal ini dapat ditunjukkan dari hasil membuatan RPP.

Pelatihan untuk guru-guru sekolah sangat penting, melalui pelatihan seperti ini guru dapat meningkatkan kemampuan mereka dalam mengajar hal ini sejalan dengan penelitian (Muhammad Djajadi, 2020) yang menyatakan aktivitas pembelajaran program pelatihan memberikan manfaat kepada guru dalam hal menambah wawasan dan pengalaman serta ilmu yang baru untuk meningkatkan kualitas pengajaran serta membantu guru dalam menyelesaikan permasalahan yang dialami baik di sekolah maupun di luar sekolah. Sehingga perlu dilakukan pelatihan secara berkala kepada guru-guru sekolah. 
1158 Pelatihan Manajemen Kelas pada Mata Pelajaran Matematika di SD IT Az-Zahra Takengon, Kabupaten Aceh Tengah - Rosliana Harahap, Nurul Qomariyah Ahmad, Ali Umar, Nurmalina DOI: https://doi.org/10.31004/abdidas.v2i5.446

\section{SIMPULAN}

1. Kegiatan pelatihan ini mampu memberi solusi alternatif untuk menanggulangi kendala yang menghambat terlaksananya kegiatan pembelajaran Matematika di SDIT Az-Zahra.

2. Kegiatan ini mampu memfasilitasi kesempatan untuk meningkatkan pengetahuan dan keterampilan guru-guru SDIT Az-Zahra.

3. Pelatihan mampu meningkatkan pengetahuan dan keterampilan khusus membuat RPP yang memamfaatkan manajemen kelas yang baik.

4. Peserta pelatihan menyambut positif kegiatan ini karena mereka mendapatkan banyak informasi tentang pengetahuan tentang manajemen kelas dan keterampilan khusus membuat RPP matematika SD.

\section{DAFTAR PUSTAKA}

Abdul Majid Dan Chaerul Rochman. (2015). Pendekatan Ilmiah Dalam Implementasi Kurikulum 2013. Remaja Rosdakarya.

Djamarah, S. B. (2006). Strategi Belajar Mengajar. Rineka Cipta.

Euis Karwati, J. D. (2015). Manajemen Kelas. Guru Profesional Yang Inspiratif, Kreatif, Menyenangkan Dan Berprestasi. Alfabeta.

G.R. Terry. (2010). Manajemen Sumber Daya Manusia. (Pertama). Kencana.

Muhammad Djajadi. (2020). Efektivitas Pendidikan Dan Pelatihan Guru: Suatu Upaya Meningkatkan Kualitas Pengajaran Fisika. Sipatokkong, 1(1), 30-44.

Rezkiatu Novia Alhikmah, Yenita Roza, M. M. (2021). Analisis Kesulitan Guru Matematika Smp Dalam Menyusun Rencana Pelaksanaan Pembelajaran (Rpp) Berdasarkan Kurikulum 2013. Cendikia, 5(1), 665-669. Https://Doi.Org/10.31004/Cendekia.V5i1.43 3

Subarinah, S. (2006). Inovasi Pembelajaran Matematika Sd. Depdiknas.
Suharsimi Arikunto, Suhardjono, S. (2007). Penelitian Tindakan Kelas. Bumi Aksara.

Suherman, E. (2003). Strategi Pembelajaran Matematika Kontemporer. Upi. 